\title{
Analisis Sentimen Terhadap Kandidat Presiden Republik Indonesia Pada Pemilu 2019 di Media Sosial Twitter
}

\author{
Cahyo Prianto, Nisa Hanum Harani, Indra Firmansyah \\ Politeknik Pos Indonesia \\ Email: ${ }^{1}$ cahyoprianto@ poltekpos.ac.id, ${ }^{2}$ nisahanum@ poltekpos.ac.id, ${ }^{3}$ indra.firmansyah007@ gmail.com
}

\begin{abstract}
Abstrak
Perkembangan teknologi saat ini telah semakin pesat dan memberikan dampak terhadap pola perilaku masyarakat yang merasakannya.Kementrian Komunikasi dan Informasi (KOMINFO) merilis sebuah data bahwa dari 265 juta jiwa penduduk Indonesia terdapat sekitar 54\% telah menggunakan teknologi internet atau sekitar 143 juta jiwa. IDN Research Institut dalam salah satu surveinya menyebutkan bahwa terdapat tiga Media Sosial yang banyak digunakan di Indonesia, yaitu Facebook, Instagram dan Twitter. Penelitian ini memfokuskan pada penggalian data berupa teks yang dihasilkan dari media sosial twitter yang merespon akun kandidat presiden RI pada pemilu 2019. Analisis sentimen diperoleh melalui klasifikasi tweet dengan menggunakan sentiment analysis Tools seperti NRC lexicon dan Bing Lexicon sehingga diperoleh informasi berupa polaritas positif dan polaritas negatif dari tweet masyarakat terhadap para kandidat Presiden di pemilu 2019. Menggunakan data bulan maret sebelum pemilu 2019, untuk kandidat 01 Joko Widodo, analisis NRC lexicon memberikan nilai sebesar 249 dan bing lexicon sebesar 267 dengan nilai rata-rata 0,11, sedangkan untuk kandidat 02 Prabowo Subianto analisis NRC lexicon memberikan nilai sebesar 195 dan bing lexicon sebesar 204 dengan nilai rata-rata 0,085. Menggunakan data bulan april setelah pemilu 2019. Kandidat 01 Joko Widodo tetap mendapatkan respon yang banyak dari masyarakat netizen tetapi nilai sentimennya bergeser ke arah lebih negatif dibandingkan dengan kandidat 02 Prabowo Subianto. Untuk kandidat 01 Joko Widodo analisis NRC lexicon memberikan nilai sebesar 17 dan bing lexicon sebesar -273 dengan nilai rata-rata $-0,246$, sedangkan untuk kandidat 02 Prabowo Subianto analisis NRC lexicon memberikan nilai sebesar 238 dan bing lexicon sebesar -73 dengan nilai rata-rata -0.02430939 .
\end{abstract}

Kata Kunci: Media Sosial, twitter, Analisis Sentimen, NRC Lexicon, Bing Lexicon, Kandidat Presiden

\begin{abstract}
The development of technology today has been growing rapidly and has an impact on the behavior patterns of people who feel it. The Ministry of Communication and Information (KOMINFO) released a data that of 265 million people of Indonesia, there are around 54\% have used internet technology or about 143 million people. In one survey IDN Research Institute said that there are three Social Media that are widely used in Indonesia, namely Facebook, Instagram and Twitter. This study focuses on extracting data in the form of text produced from social media twitter that responds to the account of the RI presidential candidates in the 2019 elections. Sentiment analysis is obtained through tweet classification using sentiment analysis tools such as NRC Lexicon and Bing Lexicon so that information is obtained in the form of positive polarity and negative polarity from community tweets towards the Presidential candidates in the 2019 elections. Using March data before the 2019 election, for candidate 01 Joko Widodo, the NRC Lexicon analysis gave a value of 249 and bing lexicon of 267 with an average value of 0.11, while for candidate 02 Prabowo Subianto the NRC Lexicon analysis gave a value of 195 and bing lexicon of 204 with an average value of 0.085 . Using april data after the 2019 election. Candidate 01 Joko Widodo still received a lot of responses from netizens but the sentiment value shifted more negatively compared to candidate 02 Prabowo Subianto. For candidate 01 Joko Widodo the NRC Lexicon analysis gave a value of 17 and bing lexicon of -273 with an average value of $-0,246$, while for candidate 02 Prabowo Subianto the NRC Lexicon analysis gave a value of 238 and bing lexicon of -73 with an average value of -0.02430939 .
\end{abstract}

Keywords: Social Media, Twitter, Sentiment Analysis, NRC Lexicon, Bing Lexicon, Presidential Candidates

\section{PENDAHULUAN}

Lahirnya internet di era tahun 1980-an telah membawa banyak perubahan terdapat perkembangan ilmu pengetahuan, pola bisnis, pola komunikasi, pola interaksi dan pola kehidupan bagi masyarakat yang merasakannya [1]. Teknologi internet telah menjadi motor berkembangnya banyak aplikasi yang digunakan. Kementrian Komunikasi dan Informasi (KOMINFO) merilis sebuah data bahwa dari 265 juta jiwa penduduk Indonesia terdapat sekitar 54\% telah menggunakan teknologi internet atau sekitar 143 juta jiwa [2].

Tahun 2019 bagi Negara Indonesia merupakan tahun politik, hal ini dikarenakan bahwa pada tahun 2019 tersebut dilaksanakan berbagai pemilihan umum yang diselenggarakan oleh KPU, seperti pemilihan kepala daerah, pemilihan anggota dewan baik itu anggota Dewan Perwakilan Daerah (DPD), anggota dewan ditingkat pusat (DPR RI) ataupun anggota dewan di tingkat wilayah baik provinsi, kabupaten atau kota (DPRD) dan juga yang tidak kalah pentingnya adalah pemilihan Presiden dan Wakil Presiden RI periode masa bakti 2019 - 2024. Fokus utama dalam penelitian ini adalah mensoroti tentang sentimen masyarakat yang ditujukan kepada pasangan kandidat Calon Presiden 2019 yaitu "Joko Widodo" dan "Prabowo Subianto". Sentimen masyarakat dalam twitter dapat dilihat dari tweet atau teks yang digunakan untuk memberikan informasi di twitter, tweet biasa digunakan oleh pengguna internet (netizen) untuk memberitahu tentang apa yang sedang dilakukan, percakapan, berbagi informasi, juga menuliskan atau mengekspresikan opini apa yang sedang dirasakan (mood) netizen [5]. Opini melalui tweet inilah yang selanjutnya akan digunakan untuk melihat sentimen yang muncul terhadap kandidat pasangan calon presiden RI 2019. Metode yang digunakan untuk mengklasifikasikan opini yang diperoleh dari tweet pada twitter adalah dengan menggunakan sentiment analysis tools yaitu NRC Lexicon dan Bing Lexicon 
dalam menentukan polaritas sentimen. Data yang digunakan dalam penelitian ini mengambilan data diambil dalam dua waktu yaitu sebelum tanggal pemungutan suara tepatnya tanggal 15 maret 2019 dan setelah tanggal pemungutan suara tepatnya 18 april 2019. Bahasa pemrogramam yang digunakan dalam penelitian ini adalah menggunakan bahasa pemrograman R i386 3.4.4 dan IDE yang digunakan menggunakan Rstudio 1.1.463.

\section{METODE PENELITIAN}

Metode penelitian yang dilakukan menggunakan alur flowchart sebagai berikut

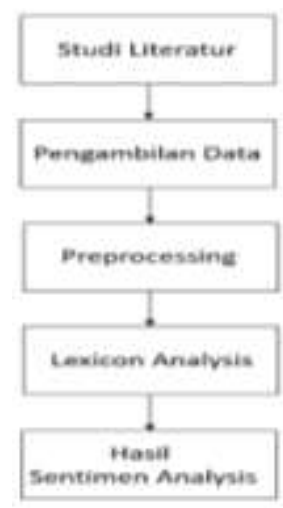

Gambar 1. Metode Penelitian

\subsection{Penelitian Terkait}

Studi literatur dilakukan untuk memperkaya referensi penelitian dengan mengambil dari buku referensi, dan jurnal yang terkait dengan tema yang sedang dibahas yaitu text mining. Berikut beberapa jurnal penelitian sebelumnya sebagai referensi :

Tabel 1. Penelitian-penelitian Sebelumnya

\begin{tabular}{|c|c|c|c|}
\hline No & Nama Peneliti & Judul & Deskripsi \\
\hline 1 & $\begin{array}{ll}\text { a. Ahmad Fathan } \\
\text { Hidayatullah } \\
\text { b. Azhari SN }\end{array}$ & $\begin{array}{l}\text { Analisis Sentimen Dan } \\
\text { Klasifikasi Kategori } \\
\text { Terhadap Tokoh Publik } \\
\text { Pada Twitter }\end{array}$ & $\begin{array}{l}\text { Menilai tokoh publik melalui media sosial twitter } \\
\text { menjelang pemilu dengan melihat sentimen analisis } \\
\text { menggunakan algortima naive bayes diolah } \\
\text { menggunakan tools Rapidminer }\end{array}$ \\
\hline 2 & Hartanto & $\begin{array}{l}\text { Text Mining Dan Sentimen } \\
\text { Analisis Twitter Pada } \\
\text { Gerakan LGBT }\end{array}$ & $\begin{array}{l}\text { Tujuan penelitian ini untuk mendeskripsikan } \\
\text { frekuensi opini kicauan di Twitter terkait pro dan } \\
\text { kontra terhadap gerakan LGBT kemudian } \\
\text { melakukan klasifikasi menggunakan analisis bing } \\
\text { lexicon }\end{array}$ \\
\hline 3 & Nur Azizah Vidya & $\begin{array}{l}\text { Twitter sentiment Analysis } \\
\text { terhadap brand Reputation: } \\
\text { Studi kasus PT.XL Axiata } \\
\text { tbk }\end{array}$ & $\begin{array}{l}\text { Penelitian ini melakukan perhitungan reputasi dari } \\
\text { produk XL axiata dan membandingkannya dengan } \\
\text { produk telkomsel dan indosat. Algoritma yang } \\
\text { dipakai seperti naive bayes, support vector machine } \\
\text { dan decission tree. }\end{array}$ \\
\hline
\end{tabular}

\subsection{Pengambilan data}

Pengambilan data melalui twitter dapat dilakukan setelah sebelumnya mendapatkan API dari media sosial twitter sehingga kita akan memperoleh consumer_key, consumer_secret_key, access_token, access_secret_key yang selanjutnya akan digunakan untuk mengakses dan mengambil data dari twitter.

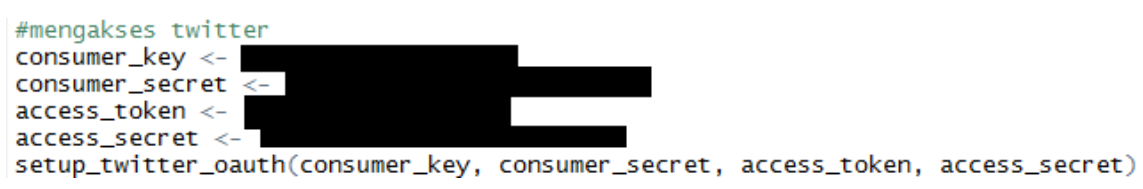

Gambar 2. Mengakses Twitter

Berikut adalah script untuk mengambil 1000 data dari twitter untuk masing-masing kandidat calon presiden 2019:

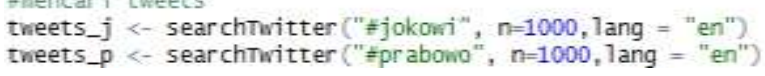


Kemudian data yang diperoleh disimpan dalam format.csv

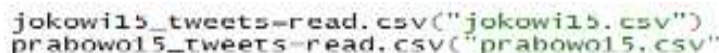

Gambar 4. Menyimpan dalam Bentuk .csv

Data yang diperoleh berdasarkan tanggal pengambilan datanya adalah sebagai berikut :

Tabel 2. Jumlah Data tweet untuk Masing-Masing Kandidat

\begin{tabular}{cccc}
\hline & Jokowi & Prabowo & Pengambilan data \\
\hline \multirow{2}{*}{ Data } & 1000 & 1000 & 15 Maret 2019 \\
& 1000 & 905 & 18 April 2019 \\
\hline
\end{tabular}

\subsection{Preprocessing}

Setelah kita memperoleh data yang kita perlukan dari twitter, maka langkah preprocessing adalah langkah penting selanjutnya. Data yang diambil dari twitter adalah data mentah yang mengandung bagian-bagian yang tidak diperlukan pada saat pengolahan data. Sehingga perlu upaya untuk mensiapkan data agar data layak untuk digunakan pada pengolah selanjutnya. Langkah preprocessing yang dilakukan :

1. Mendokumentasikan data kedalam format csv

2. Melakukan filtering data seperti : menghapus spasi berlebih, menghilangkan @username, menghilangkan tanda baca, menghilangkan link, http, https.

\section{ANALISA DAN PEMBAHASAN}

\subsection{Hasil Wikipediatrend}

Wikipediatrend adalah sebuah Library yang tersedia dalam pemrograman $\mathrm{R}$, yang digunakan untuk melihat seberapa banyak suatu artikel dalam website wikipedia.com dilihat dalam waktu tertentu. Pada penelitian ini, library wikipediatrend digunakan untuk melihat kecenderungan popularitas awal kandidat serta sebagai data pembanding sebelum penggalian data dilakukan melalui media sosial twitter tentang perilaku masyarakat di dunia maya terkait kandidat presiden Indonesia tahun 2019, yaitu artikel yang berkaitan dengan kandidat 01 Joko Widodo dan artikel yang berkaitan dengan kandidat 02 Prabowo Subianto.

Data diambil dari rentang waktu antara 1 januari 2019 sampai 17 april 2019 saat pemilihan presiden berlangsung, masing-masing artikel yang diambil datanya adalah artikel berbahasa Indonesia dan artikel berbahasa Inggris, untuk melihat seberapa besar perbandingan pembaca untuk masing-masing kandidat. Data yang diperoleh adalah sebagai berikut :

Tabel 3. Hasil Wikipediatrend Untuk Masing-masing Kandidat

\begin{tabular}{lll}
\hline Nama Kandidat & Bahasa & Jumlah viewers \\
Joko Widodo & en & 186.863 \\
& id & 501.774 \\
Prabowo & en & 157.338 \\
& Id & 932.585 \\
\hline
\end{tabular}

Perbandingan ini dapat menunjukan sejauh mana kecenderungan kandidat mana yang banyak dicari informasi profilnya. Perbandingan dapat dilihat dalam perbandingan grafik berikut :
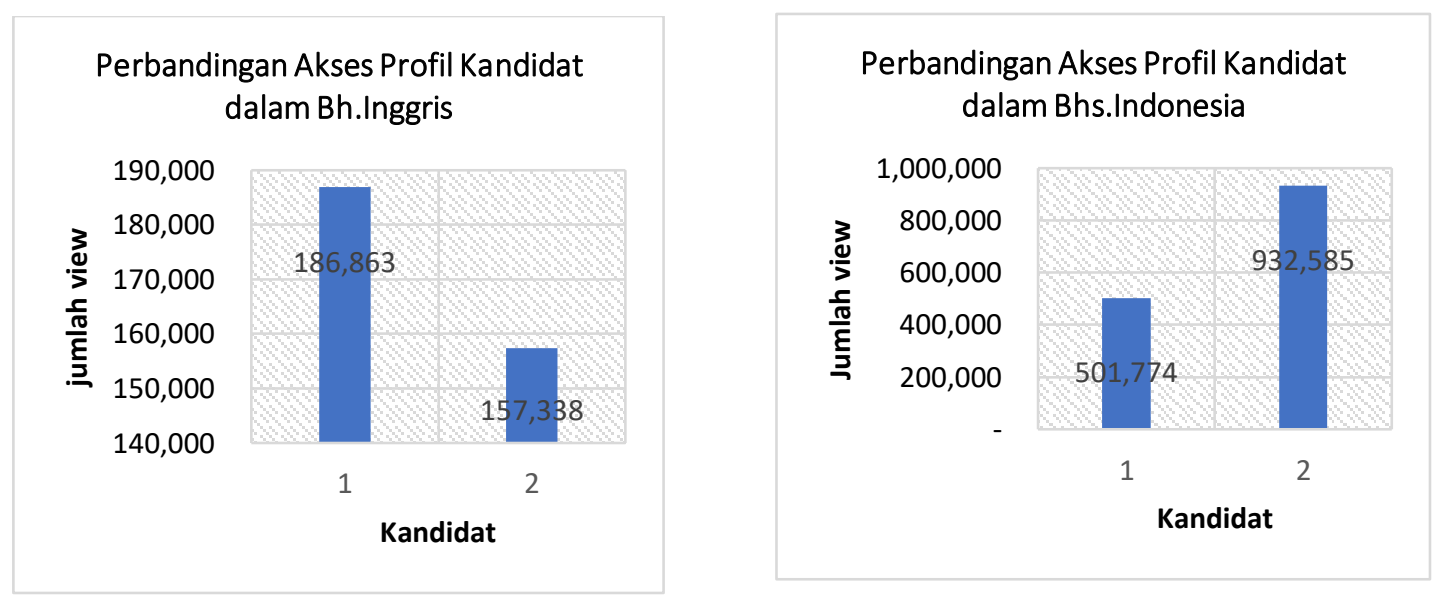

Gambar 5. Perbandingan Kandidat 
Pada gambar 5. Terlihat bahwa profil kandidat 01 Joko Widodo banyak diakses dalam halaman berbahasa Inggris dengan jumlah pengunjung 186.863 sedangkan kandidat 02 Prabowo Subianto hanya diakses sebanyak 157.338 atau $16 \%$ kurang dari kandidat 01 Joko Widodo. Pada gambar 3.2 terlihat bahwa profil kandidat 02 jauh lebih banyak diakses dalam halaman berbahasa Indonesia yaitu sebanyak 932.585 kali sedangkan kandidat 01 Joko Widodo diakses sebanyak 501.774 atau 46\% kurang dari kandidat 02 Prabowo Subianto. Dilihat dari jumlah pengunjung, kedua tokoh kandidat presiden tentunya lebih banyak dibicarakan didalam negeri, terlihat dari banyaknya pengunjung yang mengunjungi halaman berbahasa Indonesia.

Analisa selanjutnya apabila pengunjung kita lihat dalam setiap rentang bulan, maka diperoleh perbandingan sebagai berikut :

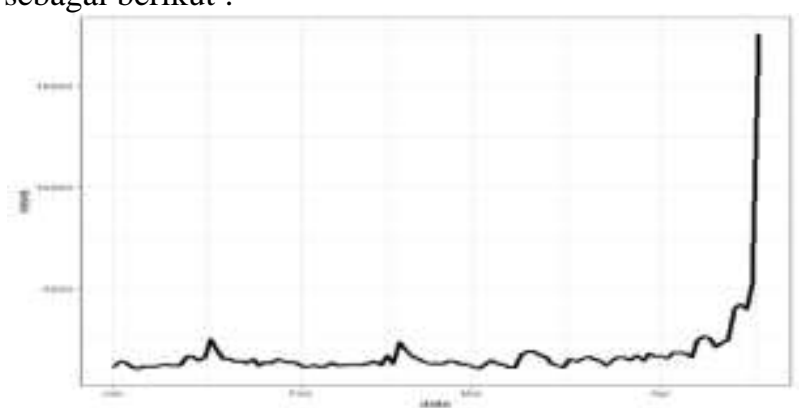

Gambar 6. Pengunjung Kandidat 01 setiap bulannya pada artikel bhs.inggris

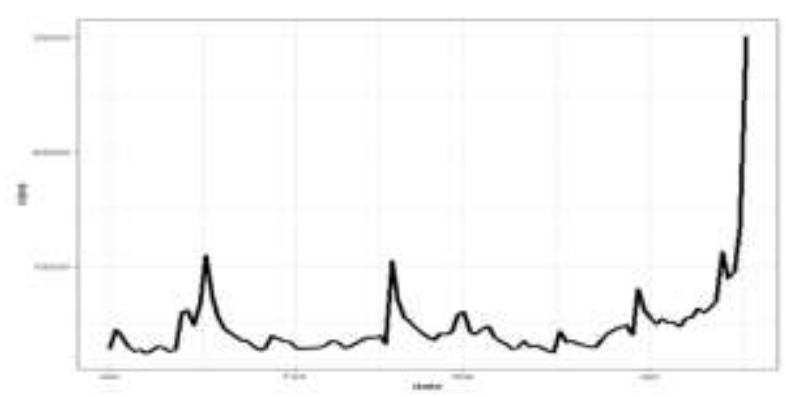

Gambar 8. Pengunjung Kandidat 01 setiap bulannya pada artikel bhs.Indonesia

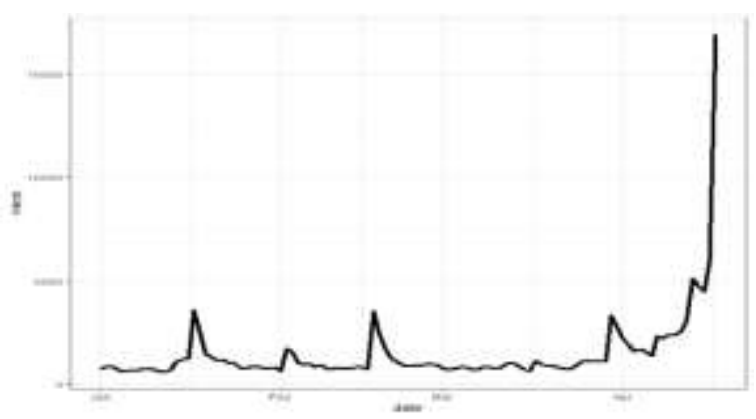

Gambar 7. Pengunjung Kandidat 02 setiap bulannya pada artikel bhs.inggris

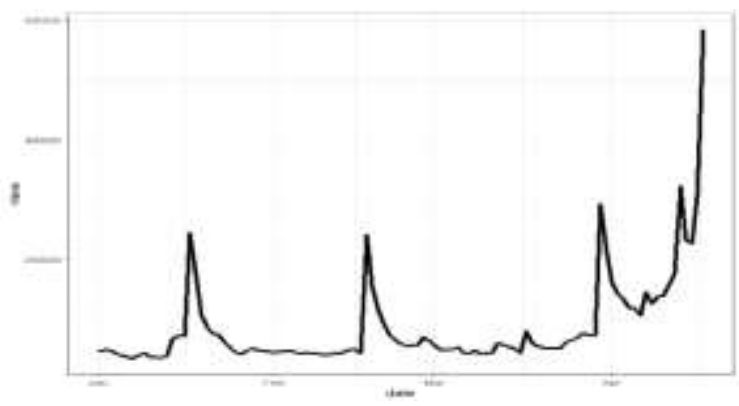

Gambar 9. Pengunjung Kandidat 02 setiap bulannya pada artikel bhs.Indonesia

Data dalam setiap gambar tersebut memberikan informasi bahwa terdapat fluktuasi pengunjung dalam setiap waktunya dan mempunyai kecenderungan yang sama untuk seluruh data bahwa menjelang pemilihan umum 17 april 2019 terdapat kenaikan pengunjung baik untuk artikel berbahasa Inggris maupun artikel berbahasa Indonesia.

\subsection{Analisis Akun Kandidat Presiden}

Setelah melihat hasil kecenderungan popularitas kandidat berdasarkan data dari wikipediatrend maka selanjutnya pada bagian ini, penulis ingin memberikan gambaran kandidat berdasarkan akun resminya pada media sosial twitter, yaitu@jokowi untuk kandidat01 Joko Widodo dan@ @ prabowo untuk kandidat02 Prabowo Subianto. Untuk melihat aktivitas dari setiap akun kandidat, penulis menggunakan aplikasi web analytics bernama Fanpage Karma yang dapat menganalisis aktivitas akun dari suatu media sosial. Berikut hasil dari Web analiytic Fanpage Karma dari akun masing-masing kandidat yang diakses pada tanggal 27 Agustus 2019:

Tabel 4. Hasil Analisis Web Analytics Untuk Akun Kandidat Pada Twitter

\begin{tabular}{lcc}
\hline \multicolumn{1}{c}{ Kategori } & Kandidat 01/ & Kandidat 02/ \\
& Joko Widodo & Prabowo Subianto \\
\hline Jumlah like & 994.048 & 88.793 \\
Jumlah Posts & 56 & 13 \\
Engagement/ keterikatan & $0.36 \%$ & $0.09 \%$ \\
Index Performa Page & $39 \%$ & $18 \%$ \\
Total reaksi (comment \& Share) & 1.204 .751 & 100.996 \\
Jumlah followers & 11.964 .876 & 4.184 .291 \\
Jumlah Post perhari & 2 & 0.46 \\
\hline
\end{tabular}


Mari kita lihat hasil web analytics menggunakan fanpage karna yang ada pada tabel 3, hasilnya dapat kita lihat bahwa di seluruh kategori yang dituliskan pada tabel 4, kandidat 01 Jokowi mempunyai nilai lebih unggul dibandingkan dengan kandidat 02 Prabowo Subianto. Hasil tersebut memberikan gambaran bahwa kandidat 01 Jokowi lebih banyak disukai, lebih banyak melakukan update status, lebih banyak menjadi perbincangan (terlepas dari perbincanganya positif atau negatif) didunia maya, serta kandidat 01 lebih banyak mempunyai followers. Hasil temuan diatas terlihat bahwa kandidat 01 berhasil memanfaatkan media sosial sebagai media untuk bersosialisasi dengan para pemilih.

\subsection{Hasil NRC Lexicon}

Setelah semua data dibersihkan maka langkah selanjutnya adalah mencocokan kata yang ada pada data dengan lexicon yang akan digunakan, data yang pertama digunakan adalah data yang berasalah dari pengambilan data pada tanggal 15 Maret 2019 yaitu sebagai berikut :

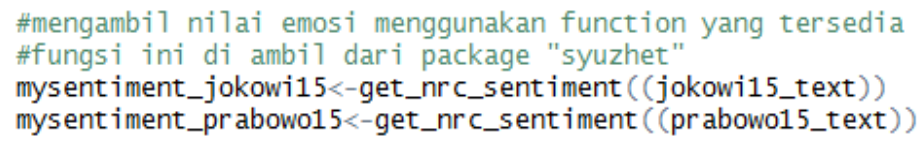

\section{Gambar 10. Menggunakan NRC lexicon}

Gambar diatas adalah script untuk mengambil data untuk kemudian dilakukan pengolahan menggunakan NRC Lexicon. Data yang diambil pada tanggal 15 maret 2019, untuk data tweet yang berkaitan dengan kandidat 01 Joko Widodo disimpan kedalam file jokowi15_text, sedangkan data untuk kandidat 02 Prabowo Subianto disimpan dalam file prabowo15_text. Hasil analisis menggunakan NRC lexicon diperoleh untuk masing-masing kandidat adalah sebagai berikut :

Tabel 5. Analisis Sentiment NRC lexicon untuk Setiap Kandidat dari data 15 Maret 2019

\begin{tabular}{llll}
\hline No & Sentiment & $\begin{array}{l}\text { Joko Widodo } \\
\text { Score }\end{array}$ & $\begin{array}{l}\text { Prabowo Subianto } \\
\text { Score }\end{array}$ \\
\hline 1 & Anger/Marah & 51 & 49 \\
2 & Anticipation/antisipasi & 234 & 228 \\
3 & Disgust/Menjijikan & 42 & 33 \\
4 & Fear/Takut & 41 & 63 \\
5 & Joy/Gembira & 233 & 112 \\
6 & Sadness/Sedih & 60 & 58 \\
7 & Surprise/Kejutan & 160 & 57 \\
8 & Trust/Percaya & 210 & 201 \\
9 & Negative & 81 & 93 \\
10 & Positive & 330 & 288 \\
\hline
\end{tabular}

Hampir disetiap kategori kandidat 01 Joko Widodo lebih banyak direspon dibandingkan kandidat 02, namun jika kita fokus pada polaritas negatif dan positif masing-masing kandidat kita mendapati bahwa kandidat 01 Joko Widodo mendapatkan sentiment negatif lebih sedikit dibandingkan kandidat 02, dan juga kandidat 01 Joko Widodo mendapatkan sentiment positif lebih banyak dibandingkan kandidat 02. Dari temuan tersebut kita menemukan kandidat 01 lebih diterima oleh netizen di media sosial twitter.

Perbandingan hasil NRC Lexicon terhadap data tweet yang diambil per tanggal 15 Maret 2019 mempunyai hasil seperti yang terlihat pada tabel 5 di atas, jika dipetakan kedalam grafik maka kita akan memperoleh perbandingan sebagai berikut :

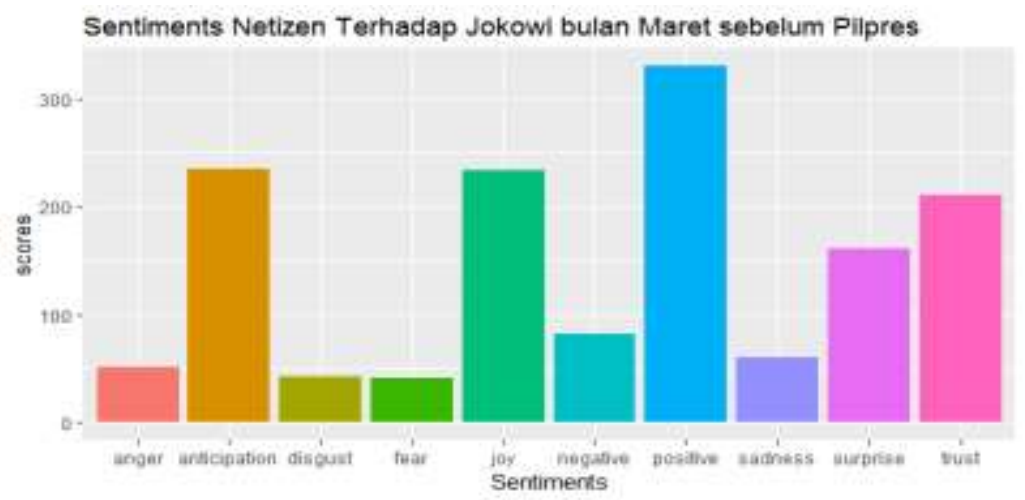

Gambar 11. Hasil Sentiment Untuk Kandidat 01 Joko Widodo 


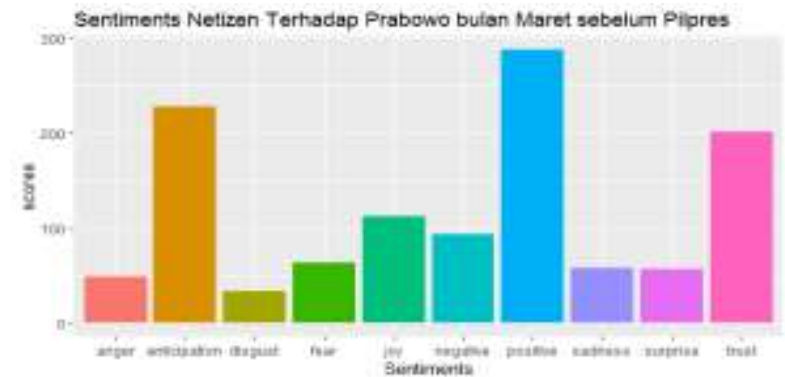

Gambar 12. Hasil Sentiment Untuk Kandidat 02 Prabowo Subianto

Untuk data yang diambil setelah waktu pemilihan umum berlangsung yaitu pada tanggal 18 April 2019, diperoleh data sebagai berikut :

Tabel 6. Analisis Sentiment NRC lexicon untuk Setiap Kandidat dari data 18 April 2019

\begin{tabular}{llll}
\hline No & Sentiment & $\begin{array}{l}\text { Joko Widodo } \\
\text { Score }\end{array}$ & $\begin{array}{l}\text { Prabowo Subianto } \\
\text { Score }\end{array}$ \\
\hline 1 & Anger/Marah & 182 & 62 \\
2 & Anticipation/antisipasi & 88 & 85 \\
3 & Disgust/Menjijikan & 127 & 10 \\
4 & Fear/Takut & 243 & 60 \\
5 & Joy/Gembira & 87 & 85 \\
6 & Sadness/Sedih & 223 & 56 \\
7 & Surprise/Kejutan & 43 & 42 \\
8 & Trust/Percaya & 200 & 111 \\
9 & Negative & 363 & 110 \\
\hline 10 & Positive & 380 & 348 \\
\hline
\end{tabular}

Untuk seluruh kategori kandidat 01 Joko Widodo mempunyai nilai score lebih tinggi dibandingkan score kandidat 02 Prabowo Subianto, jika kita focus pada klasifikasi polaritas positif dan negatif setiap kandidat, kita dapat temukan bahwa polaritas negatif dan positif untuk kandidat 01 lebih banyak dibandingkan kandidat 02 . Namun selisih untuk masing-masing kandidat pada polaritas negatif dan positif, kandidat 02 mempunyai selisih yang sangat besar, artinya yang beropini positif jauh lebih banyak dibandingkan dengan yang beropini negatif. Berbeda dengan kandidat 01 yang mempunyai selisih yang sangat tipis antara yang beropini negatif dan beropini positif, sehingga kita bisa mengatakan yang beropini negatif dan positif untuk kandidat 01 adalah hampir sama banyaknya. Perbandingan hasil NRC Lexicon terhadap data tweet yang diambil per tanggal 18 April 2019 mempunyai hasil seperti yang terlihat pada tabel 3.4 diatas, jika dipetakan kedalam grafik maka kita akan memperoleh perbandingan sebagai berikut :

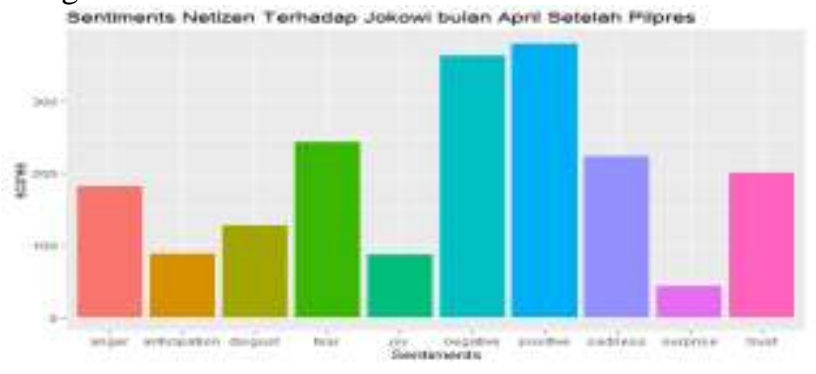

Gambar 13. Hasil Sentiment Untuk Kandidat 01 Joko Widodo

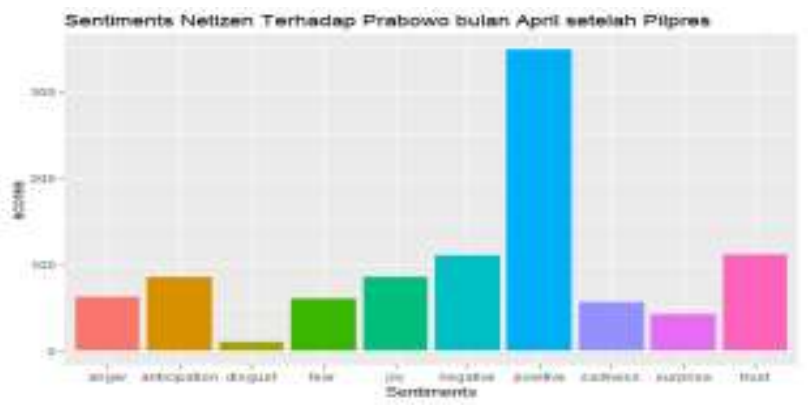

Gambar 14. Hasil Sentiment Untuk Kandidat 02 Prabowo Subianto 
Tabel rekapitulasi polaritas negatif dan positif sebelum dan sesudah Pilpres 2019

Tabel 7. Analisis Sentimen menggunakan NRC Lexicon Maret - april 2019

\begin{tabular}{lllllc}
\hline No & Kandidat & \multicolumn{3}{c}{ Maret 2019 } & April 2019 \\
\cline { 3 - 6 } & & Positif & Negatif & Positif & Negatif \\
\hline $\mathbf{1}$ & Joko Widodo & 330 & 81 & 380 & 363 \\
$\mathbf{2}$ & Prabowo & 288 & 93 & 348 & 110 \\
\hline
\end{tabular}

\subsection{Hasil Bing Lexicon}

Data yang telah diperoleh kemudian dibersihkan selanjutnya kita coba untuk melakukan analisis sentiment kembali jika sebelumnya menggunakan NRC Lexicon, maka selanjutnya adalah dengan menggunakan Bing Lexicon. Berikut adalah hasil rekapitulasi sentiment analisis, menggunakan bing lexicon dengan data bulan Maret sebelum pemilihan umum 2019 berlangsung.

Tabel 8. Analisis Sentimen menggunakan Bing Lexicon Maret - april 2019

\begin{tabular}{llllll}
\hline \multirow{2}{*}{ No } & Kandidat & \multicolumn{3}{c}{ Maret 2019 } & April 2019 \\
\cline { 3 - 6 } & & Positif & Negatif & Positif & Negatif \\
\hline $\mathbf{1}$ & Joko Widodo & 441 & 174 & 249 & 522 \\
$\mathbf{2}$ & Prabowo & 360 & 156 & 213 & 285 \\
\hline
\end{tabular}

Secara kuantitatif, analisis sentiment dapat terlihat dari banyaknya tweet bernilai positif dan bernilai negatif pada masing-masing kandidat. Mari kita perhatikan pada data yang diambil bulan maret terlihat bahwa untuk kandidat 01 Joko Widodo mempunyai sentiment positif dan sentiment negatif lebih banyak daripada kandidat 02 Prabowo Subianto. Jokowi memperoleh nilai sentiment positif 441 dan nilai sentiment negatif 174 , sehingga selisih nilainya adalah 267. Sedangkan kandidat 02 Prabowo subianto memperoleh nilai sentiment positifnya 360 dan nilai sentiment negatifnya 156 selisih nilai sentimentnya adalah 204. Pada data bulan maret ini kandidat 01 Joko Widodo mendapat respon lebih banyak dengan sentimen yang lebih positif dibandingkan dengan kandidat 02 Prabowo Subianto.

Sebaran nilai sentimen untuk masing-masing kandidat dapat terlihat pada grafik berikut :

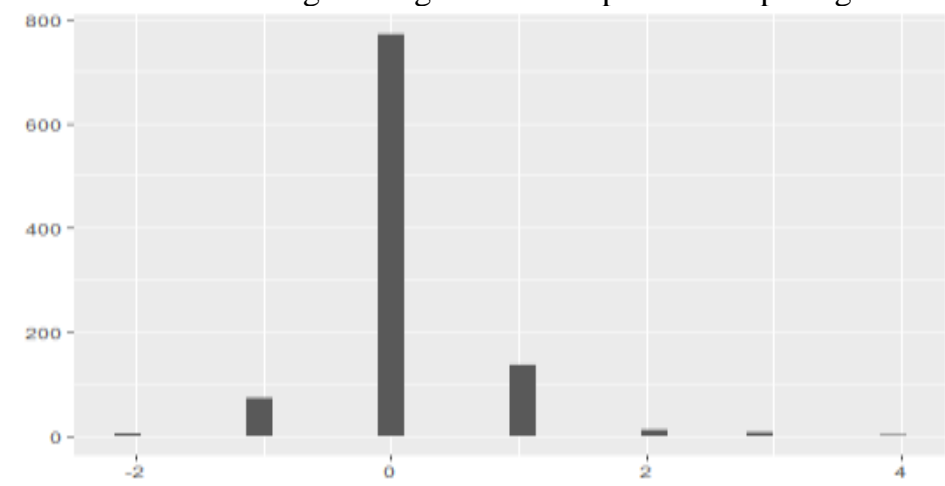

Gambar 15. Hasil Sentiment Bing Lexicon Bulan maret 2019 Untuk Kandidat 01 Joko Widodo

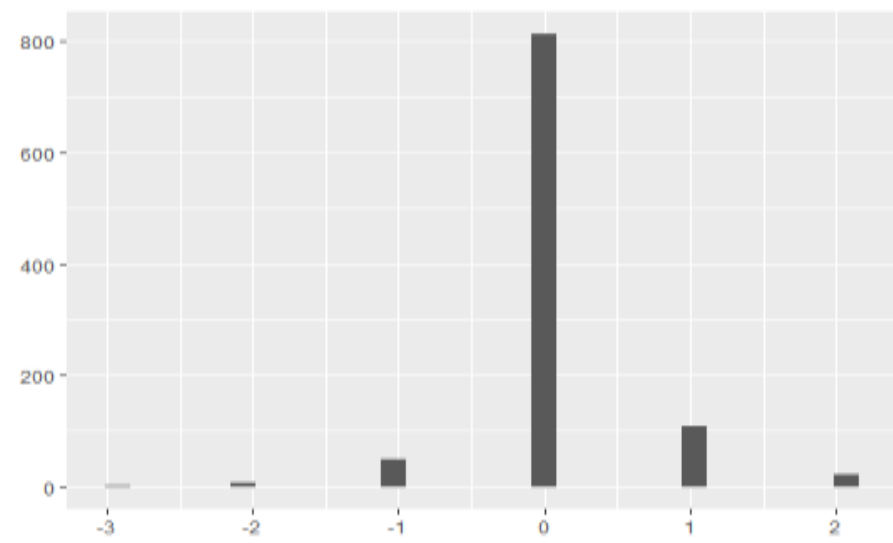

Gambar 16. Hasil Sentiment Bing Lexicon Bulan Maret Untuk Kandidat 02 Prabowo Subianto

Pada data yang diambil pada bulan april 2019, kandidat 01 Joko Widodo memperoleh nilai sentimen positif sebanyak 249 dan sentiment negatif sebanyak 522, sehingga nilai selisih sentiment secara keseluruh adalah -273, 
nilai negatif menunjukan bahwa tweet netizen di media sosial twitter untuk kandidat 01 lebih banyak yang sentiment negatif. Sedangkan untuk kandidat 02 Prabowo Subianto diperoleh bahwa nilai sentimen positif sebanyak 213 dan sentiment negatif sebanyak 285, sehingga nilai selisih sentiment secara keseluruh adalah -72 . Sentiment negatif pada kandidat 02 Prabowo Subianto tidak sebanyak sentimen negatif kandidat 01 Joko Widodo.

Grafik berikut memperlihatkan sebaran dari nilai sentimen untuk masing-masing kandidat :

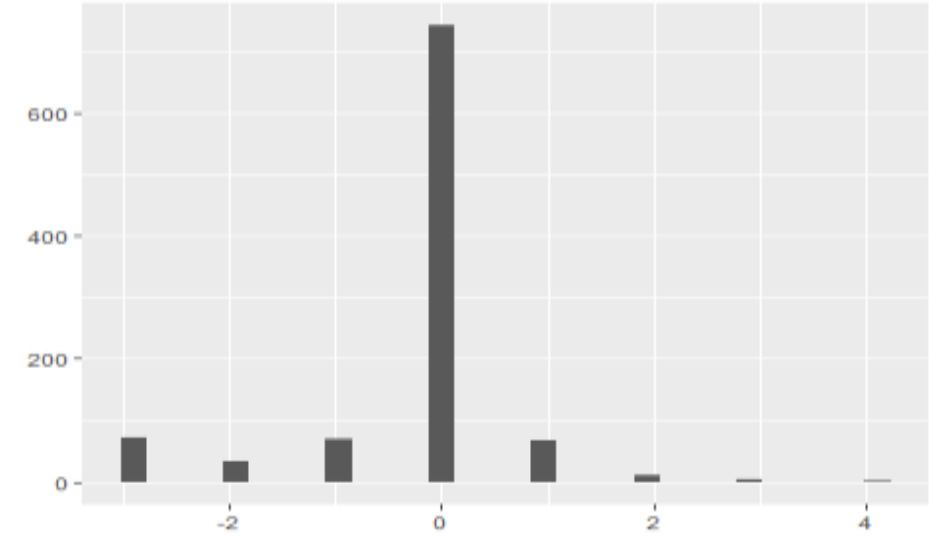

Gambar 17. Hasil Sentiment Bing Lexicon Bulan April 2019 Untuk Kandidat 01 Joko Widodo

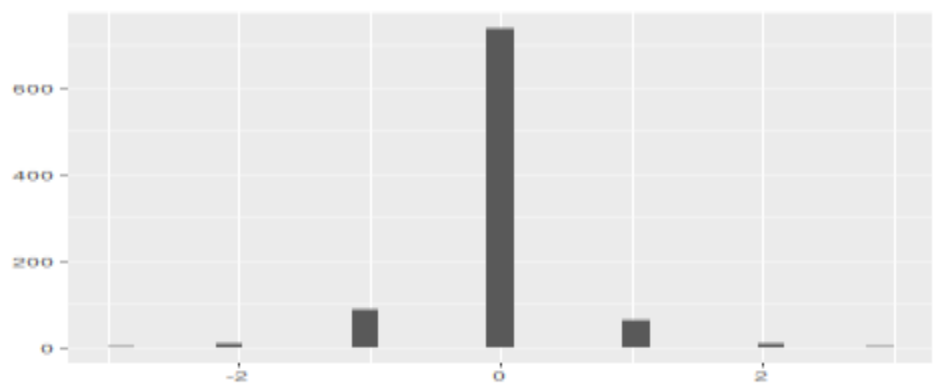

Gambar 18. Hasil Sentiment Bing Lexicon Bulan April 2019 Untuk Kandidat 02 Prabowo Subianto

Rata-rata hasil score dari Bing Lexicon dapat dilihat dari hasil dibawah ini :

Tabel 9. Rata Hasil Score Bing Lexicon Untuk Setiap kandidat

\begin{tabular}{llcc}
\hline No & Data Sentimen & Joko Widodo & Prabowo Subianto \\
\hline 1 & Maret 2019 & 0.11 & 0.085 \\
2 & April 2019 & -0.246 & -0.02430939 \\
\hline
\end{tabular}

Dari seluruh uraian data diatas dapat terlihat bahwa akun twitter milik kandidat 01 Joko Widodo banyak di respon oleh masyarakat atau netizen dari pada akun twitter kandidat 02 Prabowo Subianto, baik menggunakan analisis NRC maupun Bing Lexicon diperoleh bahwa tingkat resposibilitas twitter kandidat 01 lebih banyak, baik itu untuk sentiment positif dan juga sentiment negatifnya. Akibatnya seperti yang terlihat pada tabel 3.7 diatas, rata-rata sentiment positif kandidat 01 Joko Widodo dengan nilai 0,11 lebih besar dari pada rata-rata kandidat 02 Prabowo Subianto yang mempunyai nilai 0.085 , dan untuk sentiment negatif dari kandidat 01 Joko Widodo mempunyai nilai yang juga jauh lebih besar dari pada kandidat 02 Prabowo Subianto. Nilai rata-rata sentiment negatif kandidat 01 sebanyak -0,246 sedangkan nilai rata-rata sentiment negatif kandidat 02 sebanyak 0,02430939. Kandidat 01 Joko Widodo lebih banyak direspon netizen dibanding kandidat 02 Prabowo Subianto dengan respon Positif dan negatif yang sama banyaknya.

Berikut kami sarikan nilai selisih analisis sentimen positif dan negatif menggunakan NRC Lexicon dan Bing lexicon :

Tabel 10. Rangkuman Nilai Selisih sentimen analisis NRC Lexicon dan Bing Lexicon

\begin{tabular}{lcccc}
\hline Bulan & \multicolumn{2}{c}{ Kandidat } & 01 Joko Widodo & \multicolumn{2}{c}{ Kandidat 02 Prabowo Subianto } \\
& NRC & Bing & NRC & Bing \\
\hline Maret & 249 & 267 & 195 & 204 \\
April & 17 & -273 & 238 & -73 \\
\hline
\end{tabular}

\section{KESIMPULAN}

Hasil analisis yang telah dipaparkan sebelumnya telah memberikan kesimpulan bahwa : 
1. Media sosial twitter dapat digunakan untuk menganalisis kecenderungan sebuah opini netizen baik itu untuk analisis sebuah produk atau tokoh yang di anggap penting dalam suatu bidang.

2. Kandidat 01 Joko Widodo diketahui lebih banyak menjadi opini massa sehingga mendapatkan respon sentimen yang besar dari pada kandidat 02 Prabowo Subianto. Baik itu sentimen positif maupun sentiment negatif.

3. Menggunakan data bulan maret sebelum pemilu 2019, terlihat bahwa baik menggunakan NRC lexicon maupun Bing lexicon, kandidat 01 Joko Widodo mendapat respon lebih banyak dengan sentimen yang lebih positif dibandingkan dengan kandidat 02 Prabowo Subianto. Untuk kandidat 01 Joko Widodo analisis NRC lexicon memberikan nilai sebesar 249 dan bing lexicon sebesar 267 dengan nilai rata-rata 0,11, sedangkan untuk kandidat 02 Prabowo Subianto analisis NRC lexicon memberikan nilai sebesar 195 dan bing lexicon sebesar 204 dengan nilai rata-rata 0,085 .

4. Dengan menggunakan data bulan april setelah pemilu 2019, terlihat adanya pergeseran opini terhadap dua kandidat calon presiden. Kandidat 01 Joko Widodo tetap mendapatkan respon yang banyak dari masyarakat netizen tetapi nilai sentimennya bergeser ke arah lebih negatif dibandingkan dengan kandidat 02 Prabowo Subianto. Untuk kandidat 01 Joko Widodo analisis NRC lexicon memberikan nilai sebesar 17 dan bing lexicon sebesar -273 dengan nilai rata-rata -0,246, sedangkan untuk kandidat 02 Prabowo Subianto analisis NRC lexicon memberikan nilai sebesar 238 dan bing lexicon sebesar -73 dengan nilai rata-rata -0.02430939

\section{REFERENCES}

[1] R. Primartha, Belajar Machine Learning, Bandung : Informatika, 2018.

[2] D. Hutabarat, "Kementerian Kominfo Sebut Pengguna Internet Indonesia Capai 54 Persen," Kementrian Komunikasi dan Informatika, Jakarta, 2018.

[3] S. K. Ravindran, Mastering Social Media Mining With R, Birmingham: Packt Publishing, 2015.

[4] I. R. Institut, Indonesia Millenial Report, IDN Research Institut, 2019.

[5] S. W. S. A. D. Faishol Nur Huda, "Analisis Sentimen masyarakat Terhadap Calon Presiden Indonesia 2014 Berdasarkan Opini dari Twitter Menggunakan Metode Naive Bayes Classifier," ITSMART, vol. 2, no. 2, pp. 35 - 42, 2013.

[6] A. D. N. Mulawarman, "Perilaku Penggunaan Media Sosial Beserta Implikasinya Ditinjau dari prespektif Psikologi Sosial Terapan," Buletin Psikologi, vol. 25, no. 1, pp. 36 - 44, 2017.

[7] D. K. Wisiastuti, "Twitter sebagai Media Alternatif Informasi Publik," UIN Yogyakarta, Yogyakarta, 2014.

[8] B. P. D. P. Bahasa, Kamus Besar Bahasa Indonesia, Jakarta: Kementrian Pendidikan dan Kebudayaan Republik Indonesia, 2016.

[9] N. A. Vidya, "Twitter Sentiment Analysis Terhadap Brand Reputation : Studi Kasus PT XL Axiata Tbk," Universitas Indonesia, Jakarta, 2015.

[10] M. R. Faisal, Klasifikasi Dengan Bahasa Pemrograman R, Banjarmasin: Indonesia Net Developer Community - INDC, 2019.

[11] P. U. Gio, Belajar Bahasa Pemrograman R, Medan: USU Press, 2017.

[12] M. R. Faisal, Pengenalan Bahasa Pemrograman R, Banjarmasin: Indonesia Net Developer Community - INDC, 2016.

[13] E. W. Ira Zulfa, "Sentimen Analisis Tweet Berbahasa Indonesia dengan Deep Beliefe Network," IJCCS, vol. 11, no. 2, pp. 187 - 198, 2017.

[14] Hartanto, "Text Mining dan Sentimen Analisis Twitter Pada Gerakan LGBT," INTUISI, vol. 9, no. 1, pp. 18 - $25,2017$.

[15] A. S. Ahmad Fathan Hidayatullah, "Analisis Sentimen dan Klasifikasi Kategori Terhadap Tokoh Publik pada Twitter," in Seminar Nasional Informatika, Yogyakarta, 2014.

[16] A. A. P. J. I. Indonesia, Infografi Penetrasi dan Perilaku Pengguna Internet Indonesia, Jakarta: Technopreneur, 2017. 